臨床 アレルギー性肉芽腫性血管炎の 1 症例

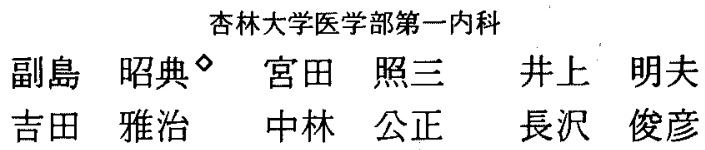

\title{
A CASE OF ALLERGIC GRANULOMATOUS ANGITIS
}

Akinori Soejima, MD, Shōzō Miyata, MD, Akio Inoue, MD, Masaharu Yoshida, MD,

Kimimasa NaKabaYASHI, MD and Toshihiko Nagasawa, MD

The First Department of Internal Medicine, Kyōrin University School of Medicine

\begin{abstract}
呅要 筋生検によつて典型的なフレルギー性肉芽腫性血管炎（以下AGA と略す）の組織像を呈し，ス テロイド治療により短期間内に諸症状の改善をみた 1 症例を経験 したので報告する。症例は56才， 女性. 副鼻腔炎に引き続き喘息様の呼吸困難が出現したが，抗生物質と気管支执張菜投与にて軽快. その後一過性の視力障害, 弛張珄高熱, 四肢のしびれ感，知覚低下が出現，著明な血沈充進と白血球 増加および好酸球增加を呈した，経過中に左腓腹筋压痛が 出現し，同部位の生検にてフィブリノイ ト壊死，内弾性板断裂を伴う血管炎像，好酸球浸潤を伴う肉芽腯性病变を認め，AGAの訩断か確定し た. ただちにプレドンソロン投与を開始したところ，1 カ月以内に全身症状，検查所見の著明な改善 を認めた。自験例を含む本邦AGA生検猃断例 9 例の 臨床経過について文嗝的考察を加えたところ， AGAは早期発見，早期ステロイド治療を行ならと，他の罗死性血管炎の範盽に属する疾患に較べてス テロイド治療が有効な例が多いことを見出した。
\end{abstract}

\section{I. 緒 㝘}

AGAは1951年Churg \& Strauss ${ }^{11}$ によつて古典的 PNから独立した壊死性血管炎の一病型として記 載された疾患である。本症は比較的希な疾患で あり，生前に確定診断を下された例は少ない、し たがつてその治療成績についても今までのところ まとまつた報告はほとんど見られない，我々は臨 床所見, 病理所見ともに典型的なAGAとみなされ る 1 症例を発症後比較的早期に診断することがで き，かつステロイド治療がきわめて有効であるこ とを確認することが出来た，本症例の詳細な経過 について報告するととむに，本症のステロイド治 療について文献的考察を行なつた成績を報告す る.

\section{II. 症 例}

〔昭和53年10月 24 日受稿〕
㭧者： KY，56才，主婦。

主訴：発作性呼吸困難, 弛張性高熱, 四肢し びれ感

家族歴：フレルギー素因なし

既往歴：昭和48年, 慢性副鼻腔炎々診断され た.

現病歴： 昭和50年秋より感昌に罹患すると喀 痰, 咳濑が著明で喀痰は黄色多量, 時に血液を混 ずることがあつた．昭和52年 9 月，歩行時に呼吸 困難出現. つづいて夜間から早朝時に発作性呼吸 困難を呈する様になり，9月13日当科に入院し た．慢性気管支炎，気管支喘息の診断のもと抗 生物質，気管支拡張薬投与にて 1 力月後に軽快退 院したが，同年11月，左眼の一過性視力障害が反 復出現し，同じ頃より左上肢のしびれ感を自覚す る様になつた１2月より左上肢に特に強い両上下 肢のしびれ感が出現し， $38^{\circ} \mathrm{C}$ 台の発熱をみる様に 


\begin{tabular}{|c|c|c|c|}
\hline (1) 血沈 & $76 \mathrm{~mm}$ (1時閒侯) & 肝機能 & 哄常なし \\
\hline (2) 血液像 & & BUN & $11 \mathrm{mg} / \mathrm{dl}$ \\
\hline $\mathrm{Hb}$ & $11.2 \mathrm{~g} / \mathrm{dl}$ & クレアチニン & $0.7 \mathrm{mg} / \mathrm{dl}$ \\
\hline $\mathrm{RBC}$ & $380 \times 10^{4}$ & (4) 血沙，兔疫学的所 & \\
\hline WBC & 12800 & Wa R & $(-)$ \\
\hline 好中球 & $65 \%$ & CRP & $5+$ \\
\hline リンハ球 & $12 \%$ & RA & $(-)$ \\
\hline 好酸球 & $18 \%$ & 抗DNA & $80 x$ \\
\hline $\begin{array}{l}\text { Pts } \\
\text { (3)海生化学 }\end{array}$ & $32.4 \times 10^{4}$ & 補体（CH50) & $41.5 \mathrm{U} / \mathrm{ml}$ \\
\hline $\begin{array}{l}\text { (3) 血没生化学: } \\
\text { TP }\end{array}$ & $7.2 \mathrm{~g} / \mathrm{dl}$ & $\begin{array}{l}\text { HB抗体・抗原 } \\
\text { ウイルス抗体価 }\end{array}$ & $\begin{array}{l}\text { (ー) } \\
\text { 有意な育動なし }\end{array}$ \\
\hline$A / G$ & 1.08 & (5)兔疫プロプリン & \\
\hline alb & $46.5 \%$ & $\operatorname{IgG}$ & $1590 \mathrm{IU} / \mathrm{ml}$ \\
\hline g) $a_{1}$ & $6.9 \%$ & $\operatorname{Ig} A$ & $410 \mathrm{IU} / \mathrm{ml}$ \\
\hline$a_{2}$ & $15.9 \%$ & $\mathrm{IgM}$ & $92 \mathrm{IU} / \mathrm{ml}$ \\
\hline$\beta$ & $9.9 \%$ & $\operatorname{Ig} E$ & 0 (感度以下) \\
\hline$\gamma$ & $20.6 \%$ & & \\
\hline
\end{tabular}

表 2 . 入院時主要検查所見 (2)

\begin{tabular}{|c|c|c|c|}
\hline (6)模尿 & & (13)気籍支造影 & $\begin{array}{l}\text { 左B.458に氛管 } \\
\text { 支照の不整を跑 }\end{array}$ \\
\hline タンバク & $(-)$ & & \\
\hline 沈渣 RBC & 5-6 כ/1 視野 & (14)気管支鏡検企 & 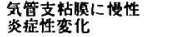 \\
\hline 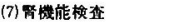 & & (15)呼吸機能榆查 & \\
\hline PSP & $18 \%$ （15分） & \%VC & $64 \%(1650 \mathrm{cc})$ \\
\hline クレナチニンクリフランス & $\begin{array}{l}56 \% \text { (total) } \\
46.6 l / \text { day }\end{array}$ & $\mathrm{FEV}_{1.0 \%} \%$ & $54 \%$ \\
\hline 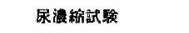 & 1.030 & RV/TLC & $46 \%$ \\
\hline DIP & 翼常なし & (6)血液ガス分析 & \\
\hline レノクラム & 巽营なし & $\mathrm{pH}$ & 7.442 \\
\hline (8)格做 & 濚血反店（+） & $\mathrm{Po}_{2}$ & $82.5 \mathrm{mmHg}$ \\
\hline (9)内分泌学的椧李 & & $\mathrm{PcO}_{2}$ & $33.6 \mathrm{mmHg}$ \\
\hline レニン活性 & $10.5 \mathrm{ng} / \mathrm{ml} / \mathrm{h}$ & 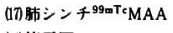 & 再下肺野に捠取聿践少 \\
\hline (10)絧菌学的检查 & & (18)筋電团 & 神経原性梦化 \\
\hline 喀玻 & 有意落㛟出されざ & 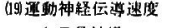 & \\
\hline (11)ECG & 觑血性変化 & 左尺周神䅅 & $43.1 \mathrm{~m} / \mathrm{sec}$ \\
\hline (12)胸部 X線写真 & $\begin{array}{l}\text { 左下肺野に䏫炎榙 } \\
\text { 影 }\end{array}$ & 左臣骨神程 & $34.3 \mathrm{~m} / \mathrm{sec}$ \\
\hline
\end{tabular}

なり，12月14日当科へ再入院した.

入院時現症：身長 $155 \mathrm{~cm}$, 体重 $51 \mathrm{~kg}$, 体温 $38.1^{\circ} \mathrm{C}$, 栄責中等. 血圧 $158 / 88 \mathrm{~mm} \mathrm{Hg}$, 脈拍 $98 /$ 分 整. 皮䖉に発疹，結節を認めず．左前頝部に半小 指頭大のリンパ節腫脹を触知, 圧痛, 発赤なく可 動性. 顔面, 下肢に浮腫なく, 眼䀫結膜, 球結膜 に貧血，黄疸を認めず，心音に異常所見なく，胸 部左下肺野に湿性ラ音聴取. 腹部に異常所見な く, 眼底はKeith-Wagener II 群. 神経学的に左 上肢に強い四肢のしびれ感および表在性知覚低 下, 四肢の腱反射に異常なく, 病的反射陰性. 筋 の圧痛，筋萎縮は認められなかつた。

入院時検查所見：表 1 , 表 2 に示寸. 血沈は 1 時間值 $76 \mathrm{~mm}$ と六進し, 血液像では白血球増加を 認め, 百分率では, 好酸球 $18 \%$ と有意な増加を示 した. 血液生化学にて 総タンパク量 $7.2 \mathrm{~g} / \mathrm{dl}$, 血

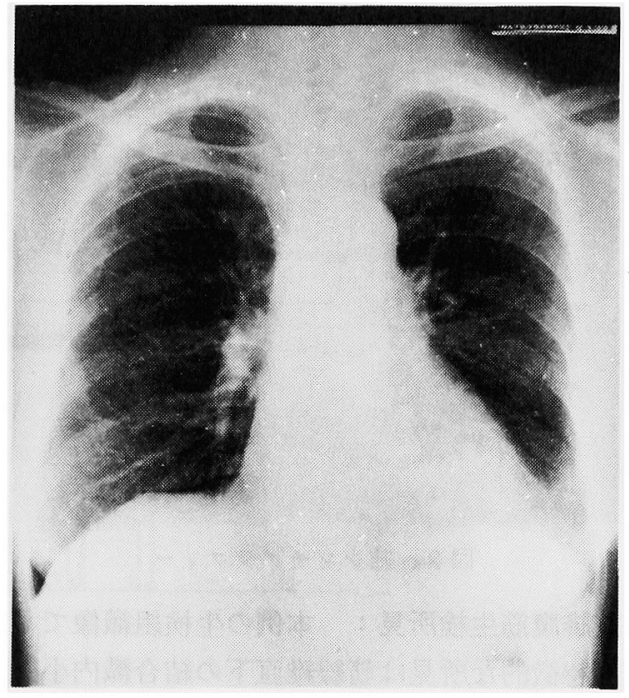

図 1. 入院時胸部 $\mathrm{X}$ 線像

清蛋白分画では $\boldsymbol{\gamma}$-グロブリン20.6\%, IgE高值は 認められなかつた. 血清, 免疫学的検査では, $\mathrm{CRP} 5+$, RAテスト (-), 抗DNA抗体 (-), $\mathrm{CH}_{50}$ 正常, $\mathrm{HB}$ 抗原, 抗体いずれる陰性であつ た．検尿にてタンパク陰性であつたが, 軽度の顕 微鏡的血尿を認めた。腎機能は軽度低下を認めた が, drip infusion pyelography, レ゙グラムに異 常所見はなかつた。検便にて 虫卵 $($ （），潜血反 応陽性を示したが，消化管造影にて出血源と思わ れる病変は認められなかつた。血浆レンン活性は $10.5 \mathrm{ng} / \mathrm{ml} / \mathrm{h}$ と高值示した. 細菌学的検查にて 喀痰, 尿に有意と認められる菌は検出されず, 結 核菌陰性，ツベルクリン反応陰性であつた. アレ ルゲン皮内反応にてカンジダに陽性を示したが， 施行した他の抗原ではいずれも陰性であつた，胸 部レントゲン検查では図 1 に示す様に左下肺野に 肺炎様陰影が認められた。気管支鏡検査では，気 管支粘膜に慢性炎症性変化を認め, 呼吸機能倹査 では混合性障害のパターンを示した. 肺シンチグ

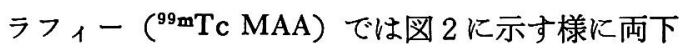
肺野に摂取率減少が認められた。筇電図にて神経 原性パターンを認め, 神経伝導速度は低下を示し た、䯣液に著明な変化は認められなかつた。 


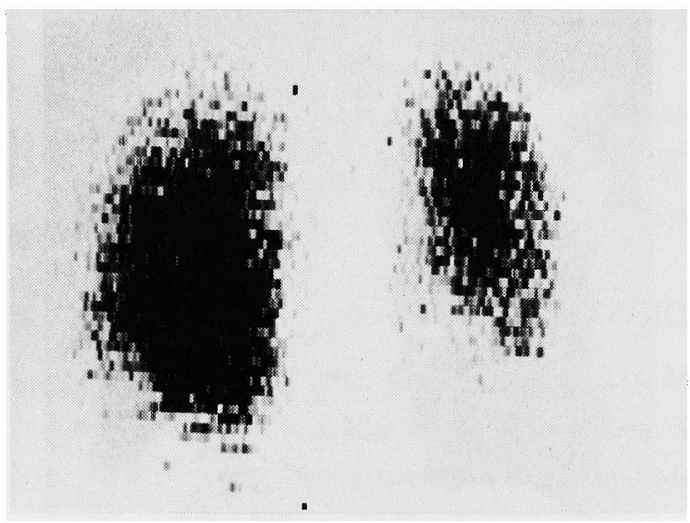

因 2、肺シンチグラフィー

左腓腹筋生検所見： 本例の生検組織像でもつ とも特徵的な所見は筋線維直下の結合織内小動脈 のフィブリノイド壊死を伴なら沉血管炎像であ る. 図 3 はHE染色, 図 4 はElastica Van Gieson 染色を示す．前者では著明なフィブリノイド壊 死，後者では内弾力板の破壊消失が著明に認めら れる. 好酸球は特に血管外膜周囲に認められた。

一方, この小動脈に近接する部位に肉芽腫性病変 が認められる(図 5，HE染色).この著明な血管 炎像を示す小動脈の末梢細動脈では内膜の肥厚と 血管周囲の軽い細胞浸潤を認めるが，著明な汎血 管炎像は認められなかつた（図6，Elastica Van Gieson染色)。なお，筋組織では間質に軽い細胞 浸潤を認める部位はあつたが，筋線維自体の変

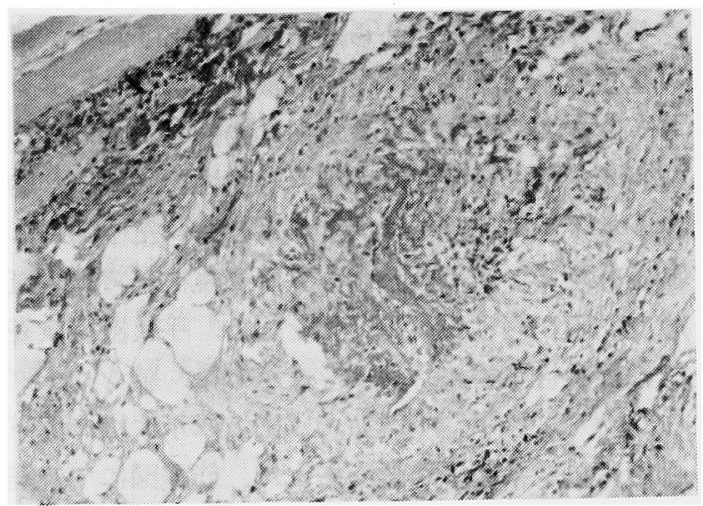

図 3.筋生検所見 (HE染色 X 400) 著しいフィブ リノイド㙗死を伴ら沉血管炎像を呈する

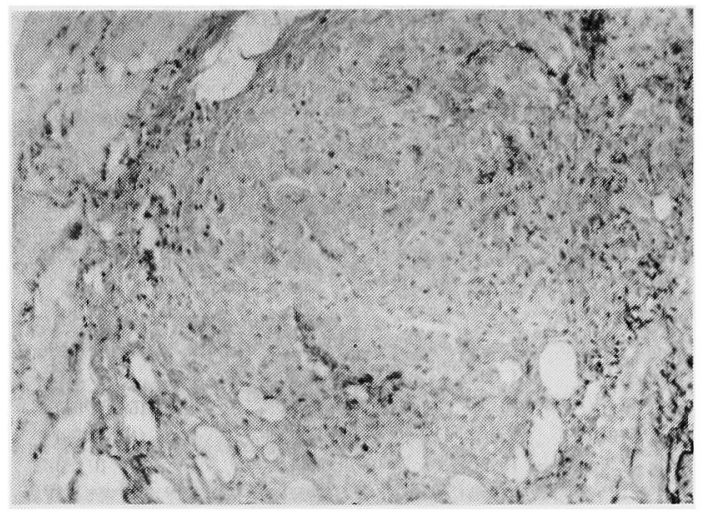

図 4.筋生㭘所見 (Elastica Van Gieson染色 $\times$ 400). 著明な内弾力板の破棲, 消失を伴 5 血管 炎像を示す

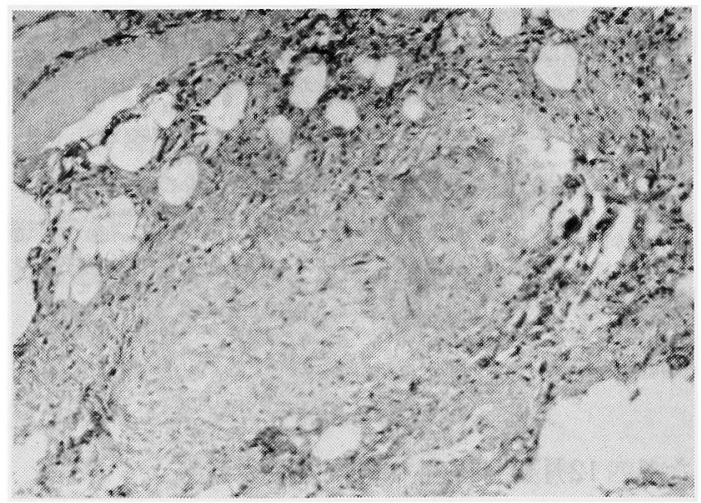

図 5.筋生㭘所見 (HE染色 $\times$ 400) 血管外肉 芽連性病变を示す。

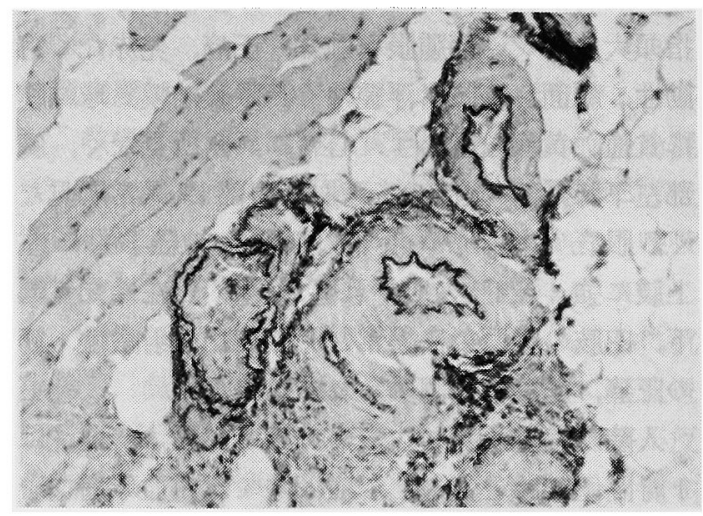

図6．笳生検所見(Elastica Van Gieson染色 $\times 200)$ 細動脈は著しい内膜肥厚像を呈する 


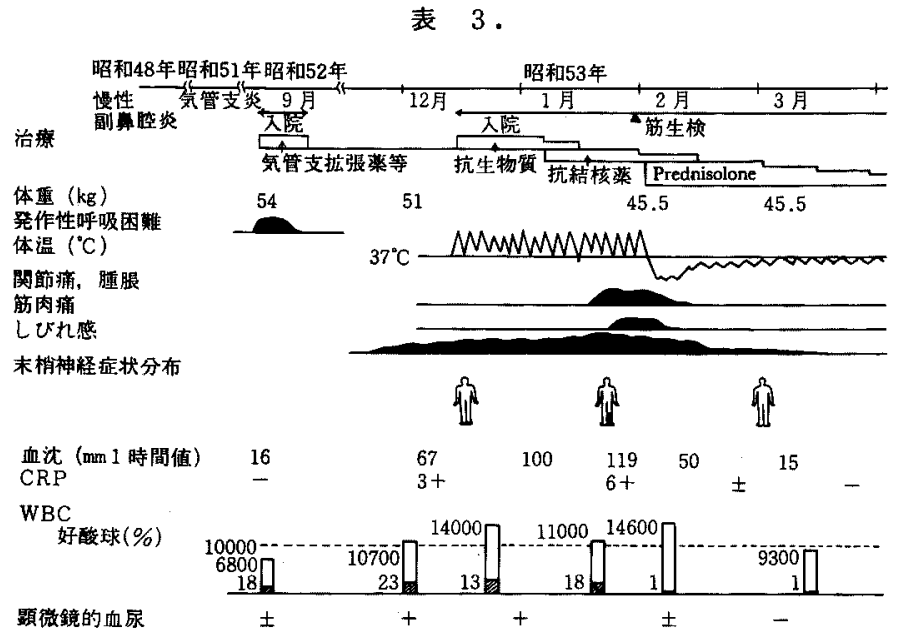

性，萎縮などの所見は認められなかつた。

経過： 表 3 に示す. 入院後も弛張性高熱が持 続し，各種抗生物質に全く反応せず，結核の治療 も試みたが、下熱傾向は認められなかつた. 血沈む 漸次増悪傾向を示し，入院 1 力月半後ステロイド 投与開始前には 1 時間值119mm と著明な促進を認 めた。 また経過中10000をこえる白血球増加を示 乙，好酸球は13〜23\%と有意な上昇を持続した。 血压は動摇を示し，時に収縮期血圧は190台まで 上昇した。また四肢末梢部のしびれ感も漸次増強 傾向を示し，特に左上下肢に强い傾向にあつた。 しびれ感の増強と共に腱反射は減弱の傾向を示 し，左アキレス腱反射，左尺骨および橈骨反射の 消失を認めたままた下肢遠位部の筋萎縮㑯向を 認め，握力は右 $8.6 \mathrm{~kg}$ ，左 $1.3 \mathrm{~kg}$ であつた。 入院 35 病日頃より左足関節部の腫脹に引き続き，左腓腹 筇痛および王痛が出現し，跛行を示す様になつた ため，1月31日左腓腹筋圧痛部位にて能生検を施 行し，前述の所見を得た. AGAの診断にてプレド ニソロン40mg連日投与を開始したところ，翌日よ り $36^{\circ} \mathrm{C}$ 台に下熱，左足関節部腫脹，筋痛の劇的改 善を認めた，血沈，CRP等の検査所見も改善し， 持続的高值を示していた好酸球増加も改善した。 投与量を漸减しつつステロイド薬投与を続け，昭 和53年 8 月現在, プレドニソロン10mg/日の維持
表 4 . 生検により診断された本邦AGA症例

\begin{tabular}{|c|c|c|c|c|c|c|}
\hline 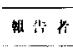 & 拄:(5) & 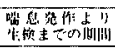 & 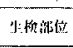 & 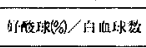 & III irige & 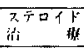 \\
\hline 1) & 4619 & 3 if & 皮湖 & $37,20,0000$ & - & 们炏 \\
\hline$=$. & $30 \times+9$ & 2 : & "F & $79 / 34,86 x)$ & - & 伴 \\
\hline 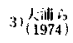 & $37 x+7$ & 4 is & 游 & 58 & - & 隹级 \\
\hline 4) & $37 \nmid 8$ & + 作 & 解 & $10 / 21,300$ & - & 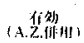 \\
\hline 5) & $29 \times 7$ & $3 n \mathrm{H}$ & 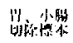 & $50 / 25,200$ & $215 \mathrm{ng} / \mathrm{mi}$ & (xis) \\
\hline 6) $\begin{array}{l}119 ! 11 \\
(1976)\end{array}$ & $22+8$ & 2.811 & 波间 & $40,7,200$ & - & 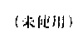 \\
\hline 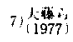 & 3217 & 6,11 & 没件 & $5,18,200$ & 1,900 / / ml & 们知 \\
\hline 8) & $16+8$ & 2 作 & 象腊 & 55. 32,3469 & $1,4500 / \mathrm{ml}$ & 1;姼 \\
\hline 9) & 5619 & 6力 列 & 募 & $23 / 10,7(8)$ & N & 该 \\
\hline
\end{tabular}

量投与にて経過良好，症状の再発をみていない。 また喘息様の発作性呼吸困難は全身症状の出現し た再入院以降全く認められなかつた。

\section{III. 考 案}

緒言にも述べた様に，AGAは1951年Churg \& Strauss $^{1)}$ により独立疾患として初めて記載された 壊死性血管炎の 1 型である，彼らによると，本症 は臨床的には副鼻腔炎，喘息発作に始ま万発熱， 反復する肺炎を初発症状とし，これらの症状が寛 解するとともに好酸球増加を伴つてPN様の多臓 器症状を呈し, 組織像では細, 小動脈から毛細 血管，静脈に及ぶ壊死性血管炎に加元，さらに血 管壁，血管外組織の肉芽腫形成，好酸球浸潤を認 める点が特徵とされている。

AGAは希な疾患であり，本邦でも生前にAGAの 
診断を下し得た例は表 4 にみるごとくきわめてわ

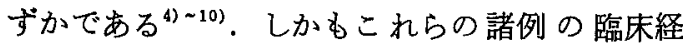
過は必ずしもChurgらの記載に一致していない。 今回我々の報告した症例は慢性副鼻腔炎，気管支 喘息発作，好酸球増加をるつて発症し，上記二症 状が寛解したのちに，好酸球增加の持続とともに 古典的PNに一致する様な罗死性血管炎による諸 症状一p女，関節炎，多発性単神経炎を主症状と し，その他視力障害，腎の細，小動脈の血管炎に 基づくと推定される高血圧, 腎機能低下, 高レニ ン血症などの症状が加わつている一が出現してい る.このような臨床経過はChurgらの報告した13 例のAGAの臨床像に汇注一致するもので，いわば AGAの典型的臨床像を示した例といえよう。

肺病变を伴ら壊死性血管炎は, Churgらの報告 後もな和Rose \& Spencer ${ }^{11)}$ (1957) が罗死性血 管炎を肺症状を伴う群としからざる群の二つ に分けて整理していることからもかかる様に， AGA，過敏症性血管炎，Wegener肉芽腫症などそ の基礎疾患は多様で，臨床的に原疾患を想定する ことは必ずしも容易ではない，ところが我々の症 例は臨床的に極めて二ニークな経過をとり，必ず しも組織所見の裏付けがなくとも充分AGAを疑い 得た例である。この点, AGAは肺病変を伴う壊死 性血管炎のなかです特異的な位置付けをし得る疾 患と思われる。

一方，本症例の臨床経過で注目すべきことはス テロイド治療が劇的に奏効し，短期間のらちに諸 症状，検査所見が改善し，経過表（表 4) にみる 様に現在プレドニソロン $10 \mathrm{mg} /$ 日 の維持量投与で 完全寛解を続けていることである。これは，古典 的PNを始め，罣死性血管炎を主徵とする諸疾患 では一般にステロイド治療に抵抗性のことが多い との通念から外れる所見である. 特に生検組織で ほとんど血管内曌の閉塞している像を呈していた ことから，ステロイド投与前にはこの様に短期間 内に寛解することは考えにくかつたのである. そ こで，生前に生検によりAGAと診断された本邦 8 症例のステロイド治療成績を文献的に考察してみ
ると，表 4 に示すように，ステロイド未使用の 1 例を除いてすべてステロイド薬が著効を示すとの 成績を得た。この事実はChurgらの報告したいわ ば古典的AGAは独特な臨床経過を示すと同時にス テロイド治療に極めて良く反応する壊死性血管炎 であることを示唆して括り，壊死性血管炎の臨床 上極めて重要なことといえよう。

\section{IV. 結 語}

発症後比較的早期に，筋生検により診断を下し 得たAGAの 1 症例を報告した。本症例の経験から 定型的AGAでは発症時上り特徴的な臨床経過，臨 床像を示し，AGAK対する一般的認織が深まれ ばそれのみからAGAの彔いをもつことは必ずし る困難ではないるのと思われる。また，自験例の みならず，本邦の生検により診断されたAGA報告 例もすべてステロイド薬によく反応している。し たがつて臨床的にAGAの疑われる症例は，積極的 に生検による確定診断をすする，重篤な非可逆性 の缄器症状の出現以前にステロイド治療を開始す ることによつて，比較的良好な予後を期待し得る むのと考えられる.

\section{文 献}

1) Churg J and Strauss L: Allergic granulomatosis, allergic angiitis, and periarteritis nodosa. Amer J Path 27: 277, 1951.

2) Sokolov RA, et al: Allergic granulomatosis. Amer J Med 32: 131, 1962.

3) Varriale P, et al: Allergic granulomatosis. Case report and review of the literature. Arch Intern Med 133: 235, 1964.

4) 加納 正, 他 : Allergic granulomatous angiitis の典型的な 1 症例とくに周辺疾患之の関係な らびに成因に関する検討. 日内会誌 $66: 1461$, 1977.

5) 横山芳正, 他 : Allergic granulomatous angiitis の 1 例. 日内会誌 $64: 565,1975$.

6) 田中昌媈，他：アレルギー性血管炎の1例，日 内会誌 $65: 1421,1976$.

7）西戸孝昭，他：好酸球增多と肺野の浸潤陰影を 主徵とする結節性多発動脈炎 (Churg \& Strauss 型 PN) とついて。臨木兔疫 $5: 515,1973$.

8）相沢好治，他：腸穿孔をくり返し azathioprine の奏効した多発性動脈炎の 1 例, 一periarteritis nodosa 但lergic granulomatous angitis 
日本臨床 $32: 3634,1974$.

9) 大浦孝, 他 : Polyneuritis を初徽とした allergic granulomatous angitis と思われる1例，日 内会誌 $63: 611,1974$.

10) 大藤 真：原病と好酸城増多。内科 40 ： $223,1977$.

11) Rose, GA and Spencer, H: Polyarteritis nodosa with pulmonary involvement. Quart J Med 26: 43, 1957.

12) 川浪千寻, 他: Allergic granulomatous angitis の 1 剖検例. 日内会誌 $64: 396,1975$.

13) 平間元博, 他 : Allergic granulomatous angitis
の 1 剖検例. 北海道医学雑誌 $46: 117,1971$ 。

14) 厚美利行, 他 : 臨床上気管支喘息重積状態を呈 乙, 剖検上 allergic granulomatous angitis を 示した 1 症例。日内会誌 $53: 595 ， 1964$.

15) 岡田朝生, 他: 呼吸器疾患々好酸球增多. 内科 $40: 216,1977$

16)細田泰弘：膠原病の血管病变, 最新医学 24 : $2060,1969$.

17) 山田定, 他: Allergic granulomatous angitis (Churg and Strauss) の2 例. リウマキ 16: 533, 1976. 